\title{
In vitro and in vivo effects of Enterococcus faecalis CECT7121 on Toxocara canis
}

\author{
Paula G Chiodo, Mónica D Sparo, Betina C Pezzani, Marta C Minvielle ${ }^{+}$, Juan A Basualdo \\ Cátedra de Microbiología y Parasitología, Facultad de Ciencias Médicas, Universidad Nacional de La Plata, \\ Calle 60 y 120, 1900 La Plata, Argentina
}

\begin{abstract}
The aim of the present paper was to evaluate the larvicidal effect of Enterococcus faecalis CECT7121 (Ef7121) on the Toxocara canis cycle both in vitro and in vivo. For the in vitro experiments, T. canis larvae were incubated with the supernatants of Ef7121 (EI) and mutant Ef7121 (EIm), in a pre-culture of Ef7121 (EII) and in a fresh culture with Ef7121 (EIII) and the Ef7121 mutant strain (EIIIm). The viability of the larvae was calculated after a $48 \mathrm{~h}$ incubation. A significant reduction of the viability of T. canis larvae was observed in EI, EII and EIII. A decrease of this inhibitory effect was observed in EIm and EIIIm $(p=0.008)$. In the in vivo experiments, mice were orally inoculated with three doses of Ef7121. To study the probiotic persistence in the intestine, the animals were sacrificed every four days and their intestines were dissected. The initial average bacterial levels were $9.7 \times 10^{4}$ for Ef7121 (colony forming units $/ g$ ). At the end of the assay the levels were $1.46 \times 10^{4}$. No bacterial translocation was detected in mesenteric lymphatic nodules and spleen. Ef7121 interference with the biological cycle was evaluated in mice challenged with T. canis. The interference was significant when the mice were challenged with probiotic and $\mathrm{T}$. canis simultaneously $(p=0.001)$, but it was not significant when the challenge was performed 15 days after administration of the bacterial inoculum $(p=0.06)$. In conclusion, Ef7121 possessed in vitro and in vivo larvicidal activity.
\end{abstract}

Key words: Enterococcus faecalis CECT7121 - Toxocara canis - probiotics - biological cycle

Toxocariasis is a cosmopolitan parasitic saprozoonosis widespread in both well-developed and developing countries (Despommier 2003). Infectious ova excreted by canids harbouring these highly fecund parasites contaminate the environment, exposing paratenic hosts, including humans, to the risk of infection (Holland \& Smith 2006). Larvae hatch in the small intestine and migrate to other organs via the portal circulation (Fan et al. 2004). They have been described in the liver, lungs, heart and brain (somatic migration). The migration of Toxocara canis in human tissues causes visceral or ocular larva migrans (Pecinali et al. 2005). There are other forms of clinical diseases such as covert, neurological, asthmatic and asymptomatic toxocariasis (Chiodo \& Basualdo 2008). Paratenic hosts (humans, rodents, birds) have been described in the natural cycle of this parasite, in which the larvae can survive for years in hypobiosis in tissues (Magnaval et al. 2001).

In canines, $T$. canis mainly affects puppies and young animals and causes a cough with nasal discharge that can be fatal or may disappear after three weeks. When worms are present in the stomach and intestine, they cause vomiting and/or diarrhoea with resultant dehydration. Puppies can suffer pneumonia due to the aspiration of vomit. Chronic infection in puppies and older dogs leads to a progressive malnutrition. It may cause intermittent diarrhoea or convulsions (De la Fé Rodríguez et al. 2006).

Financial support: UNLP, CIC, Fundación Roemmers + Corresponding author: mminviel@med.unlp.edu.ar Received 11 November 2009

Accepted 12 May 2010
Several T. canis infection prevalence studies have been conducted using urban pets and street dogs (Minvielle et al. 2003, Sánchez Thevenet et al. 2003). In Argentina, a study of over 1,000 urban dogs revealed a prevalence of toxocariasis of $10 \%$, which increased to $30 \%$ when only dogs younger than one year old were considered (Pereira et al. 1991). In studies of the human population, Minvielle et al. (2000) demonstrated a seroprevalence of $10 \%$ in blood donors and Chiodo et al. (2006) showed a seroprevalence of $23 \%$ in rural areas.

All of these data indicate that toxocariasis constitutes a public health problem with a great impact in our region. Control measures that can be applied for the treatment of these zoonoses are the administration of chemical antiparasitic drugs in the definitive host and vaccine development. Unfortunately, the efficacy of antiparasitic drug use is limited by the development of resistance, which has been recorded in recent years (Bautista-Garfias et al. 2002). These findings have driven the search for alternative strategies to control parasitoses (Waghorn et al. 2002).

In the context of these findings, the use of naturally antagonistic microorganisms is a plausible alternative to traditional measures employed for the control of toxocariasis (Benítez et al. 2000). The use of probiotics prevents the intestinal infection in animals and in in vitro models (Pollmann et al. 2005). Probiotics are defined as viable microorganisms that, in sufficient amounts, reach the intestine in an active state and have a positive health effect (de Vrese \& Schrezenmeir 2008). The mechanisms of action of probiotics include competition for intestinal surface receptors, stimulation of humoral immunity, secretion of extracellular factors with antimicrobial activities (organic acids and bacteriocins) and competition with pathogens 
for intraluminal nutrients (Rolfe 2000, Schrezenmeir \& de Vrese 2001, Duggan et al. 2002). Whereas probiotics have been used successfully for the treatment of several intestinal disorders (Heyman 2000, de Vrese \& Schrezenmeir 2008), they have not yet been applied for the control of human intestinal parasitoses. However, they have been used successfully in animals for the treatment of parasitoses, such as cryptosporidiosis, giardiasis, trichinellosis and babesiosis (Alak et al. 1999, Bautista-Garfias et al. 2001, 2005, Humen et al. 2005). In contrast, Dea-Ayuela et al. (2008) reported that Lactobacillus casei facilitated experimental infection with Trichuris muris, whereas Guitard et al. (2006) could not eradicate cryptosporidiosis in rats by the administration of L. casei.

Enterococcus faecalis CECT7121 (Sparo \& Mallo $2001)$ is a probiotic with inhibitory activity against Grampositive and Gram-negative bacteria such as Listeria spp, Staphylococcus aureus, Clostridium spp, Bacillus spp, Escherichia coli, Shigella sonnei and Shigella flexneri (Sparo et al. 2006). This strain can adhere and persist in the murine intestinal epithelium (Basualdo et al. 2007).

Among the possible negative effects of probiotic foods, is the risk for bacterial translocation into vital organs (Pavan et al. 2003). Most pathogenic enterococci are able to translocate from the intestinal lumen to the mesenteric lymph nodes, liver and spleen (Koch et al. 2004). Hemolysin and gelatinase are virulence factors involved in the translocation of these enterococci. E. faecalis CECT7121 lacks genes that code for hemolysin and gelatinase and is devoid of a capsule (Sparo et al. 2008). Electrophoretic analysis of plasmid DNA revealed that $E$. faecalis CECT7121 contains only one plasmid.

After novobiocin treatment, all viable cells lacking the plasmid demonstrate no inhibitory activity against mentioned Gram-positive and Gram-negative bacteria ( $E$. faecalis CECT7121m). Mutant as well as wild-type bacteria display the same phenotypic pattern (Sparo et al. 2006).

Our research group has demonstrated that oral treatment with E. faecalis CECT7121 significantly reduces the quantity of larvae recovered from the liver and lungs of mice infected by T. canis (Basualdo et al. 2007). To expand this research, the aim of the present study was to evaluate the effect of E. faecalis CECT7121 on the biological cycle of $T$. canis both in vitro and in vivo.

\section{MATERIALS AND METHODS}

Initial culture (IC) - E. faecalis CECT7121 (Ef7121) and mutant (lacking plasmid) E. faecalis CECT7121 $(E f 7121 \mathrm{~m})$ strains were used (Sparo et al. 2006). Both strains were cultured for $24 \mathrm{~h}$ at $35^{\circ} \mathrm{C}$ in triptein soy agar (Laboratorios Britania, Buenos Aires).

Egg recovery - T. canis adult females were cleaned with $1 \% \mathrm{NaOH}$, cut into small segments and the eggs were extracted. The eggs were incubated for 40 days at RT until the infectious stage was reached (Oshima 1961) and then they were quantified by optical microscopy using a Sedgwick-Rafter chamber.

Larval recovery - The infectious larvae were obtained by mechanical decortication. The eggs were disinfected superficially, placed in an Erlenmeyer flask containing glass pearls and placed in a shaker for $10 \mathrm{~min}$. This suspension was then poured into a sterile Baermann funnel containing $20 \mu \mathrm{g} / \mathrm{mL}$ gentamicin and was kept at $35^{\circ} \mathrm{C}$ for $24 \mathrm{~h}$. Larvae were stored together in one sterile tube.

Mice - NIH-Swiss male mice, 25-30 g, were used (Veterinary Science School of Veterinary Science Biotery, Universidad Nacional de La Plata). The animals were maintained under controlled food, light/darkness cycles and temperature conditions. All procedures used for animal manipulation were approved by Argentinean laws (ANMAT 1996).

\section{In vitro assays: $E f 7121$ and $T$. canis incubation}

Experiments (E) I and EIm - One hundred twenty $T$. canis larvae were incubated in the supernatant from five IC colonies of Ef7121 (EI) and Ef7121m (EIm) grown in brain heart infusion (BHI) for $48 \mathrm{~h}$ at $35^{\circ} \mathrm{C}$. The supernatant was obtained by centrifugation at $5800 \mathrm{~g}(15 \mathrm{~min})$ and $7000 \mathrm{~g}(10 \mathrm{~min})$ to remove the cells. The incubation was carried out for $48 \mathrm{~h}$ at $30^{\circ} \mathrm{C}$.

EII (pre-culture) - Five IC colonies were grown in $3 \mathrm{~mL}$ of BHI broth $\left(48 \mathrm{~h}, 35^{\circ} \mathrm{C}\right)$. Subsequently, 120 larvae were co-incubated for $48 \mathrm{~h}$ at $30^{\circ} \mathrm{C}$.

EIII and EIIIm - One hundred twenty larvae were co-incubated in $3 \mathrm{~mL}$ BHI broth inoculated with five IC colonies. The incubation was carried out for $48 \mathrm{~h}$ at $30^{\circ} \mathrm{C}$. An identical experiment was performed with the Ef7121 mutant strain (EIIIm).

EIV - As a control group, 120 T. canis larvae were incubated in BHI broth without a bacterial inoculum.

Each assay was carried out in triplicate and was assessed via the observation of $T$. canis larvae by light microscopy. The viability of the larvae was quantified according to Satou et al. (2005): (i) dead larva, (ii) mobile, using part of the body, and (iii) mobile, using all of the body. Scanning electron microscopy (JEOL model 6360 LV) was also used for sample observations.

The bacterial counts were carried out using triptein soy agar serial dilutions following the larval incubation. The $\mathrm{pH}$ was measured daily (Macherey-Nagel Laboratories, Germany).

Data were analyzed by analysis of variance (ANOVA) (version 3.05 of the InStat software package GraphPad, San Diego, CA, USA).

\section{In vivo assays}

Ef7121 persistence in the murine gastrointestinal tract - Bacterial suspensions in BHI were prepared daily from an overnight culture of Ef7121 that was centrifuged (5800 $\mathrm{g}$ for $15 \mathrm{~min}$ ) and washed with sterile saline solution (SFe). In total, 21 mice were inoculated orally with $25 \mu \mathrm{L}$ of the bacterial suspension $\left[1 \times 10^{8}\right.$ colony forming units (CFU)] daily for three consecutive days. Animals were sacrificed every four days. The intestine was extracted to determine the quantity of $E f 7121$ and $E$. coli as an indicator of the normal microbial flora (E. coli recounts were performed to demonstrate that the probiotic did not displace the normal microbial flora). Ef7121 intestinal colonization was evaluated by recounting the 
bacteria present in the intestine (CFU/g). The phenotypic characterization of enterococci and enterobacteria was carried out by Gram staining, cultivation in differential media and biochemical tests (Sparo et al. 2008). Ef 7121 colonies were identified based on their inhibitory activity against Listeria monocytogenes CEB101 (Sparo et al. 2008). The mesenteric lymph nodes and spleens of inoculated mice were dissected and cultured to evaluate any possible bacterial translocation (Basualdo et al. 2007).

Co-infection with T. canis - Thirty-two mice were inoculated orally with $1 \times 10^{8} \mathrm{CFU}$ of $E f 7121$ for three consecutive days. Half of the mice were infected with 200 T. canis eggs together with the last dose of enterococci (Group A). The remaining mice were infected 15 days after probiotic treatment with the same egg doses (Group B). Three controls were used for each group: (i) CI: mice inoculated with $T$. canis eggs in SFe; (ii) CII: mice inoculated with the Ef7121 suspension; (iii) CIII: mice inoculated with SFe only. The mice were sacrificed $72 \mathrm{~h}$ after infection with T. canis. The intestine, liver and lungs were dissected. Ef7121 colonization of the intestine was assessed by CFU counts (CFU/g) (Sparo et al. 2008). The quantity of $T$. canis larvae in the liver and lungs was determined by light microscopy prior to peptic digestion ( $1 \%$ pepsin in $\mathrm{pH} 1.5$ glycine buffer).

The results were analyzed by the Mann-Whitney Utest (version 3.05 of the InStat software package GraphPad, San Diego, CA, USA).

\section{RESULTS}

The Table shows the results obtained for the in vitro Ef7121-T. canis larvae assays after $48 \mathrm{~h}$ of co-incubation. The ANOVA results showed that the differences among the groups were very significant $(p=0.008)$. The average enterococcus count in these assays was $4-6 \times 10^{8}$ $\mathrm{CFU} / \mathrm{mL}$. The purity and viability of the bacterial culture were maintained for the duration of the experiment and there were no $\mathrm{pH}$ variations. Microphotographs of the interaction between Ef7121 and T. canis are shown in Figs 1 and 2 and electron micrographs demonstrating their interaction are shown in Fig. 3. The micrographs revealed the adhesion of the enterococci to the surface of the larvae.

Concerning persistence, the average bacterial levels in the intestine (CFU/g) were initially $9.7 \times 10^{4}$ for Ef7121 and $2.7 \times 10^{5}$ for E. coli. At the end of the assay, they were $1.46 \times 10^{4}$ for $E f 7121$ and $9.2 \times 10^{4}$ for E. coli. Fig. 4 shows the recounts of both bacteria on different days of observation. No bacterial growth was observed in the lymph nodes or spleens analyzed.

The counts obtained for the probiotic strain/E. faecalis CECT7121 in mice challenged with $T$. canis were $2.53 \times 10^{4}$ [standard deviation (SD) $=1.5 \times 10^{4}$ ] CFU/g in the small intestine in group $\mathrm{A}$ and $2.3 \times 10^{4}(\mathrm{SD}=$ $\left.1.9 \times 10^{4}\right) \mathrm{CFU} / \mathrm{g}$ in the corresponding control (CIIA). For group B, the recounts were $3.44 \times 10^{5}(\mathrm{SD}=2.38 \mathrm{x}$ $\left.10^{5}\right) \mathrm{CFU} / \mathrm{g}$ and $1.7 \times 10^{5}\left(\mathrm{SD}=2.01 \times 10^{5}\right) \mathrm{CFU} / \mathrm{g}$ in the control (CIIB). No bacterial counts were obtained from the large intestine. In controls CI and CIII for groups $\mathrm{A}$ and $\mathrm{B}$, the probiotic strain/E. faecalis CECT7121 was not present. Fig. 5 shows the average recovery of $T$. canis larvae from the liver and lungs.

\section{DISCUSSION}

In previous research, we indicated that the Ef7121 probiotic reduced the parasite burden in mice infected with $T$. canis (Basualdo et al. 2007). In the present paper, we studied the effect of this strain on the in vitro culture of $T$. canis larvae and the in vivo persistence of $T$. canis in the murine intestine. We also studied the effect of several T. canis challengers to evaluate the activity of this probiotic in detail.

The present study showed that the cell-free supernatant (EI), the pre-culture obtained from the $48 \mathrm{~h}$ cell culture (EII) and the co-culture of Ef7121 (EIII) significantly reduced the viability of $T$. canis larvae. A decrease of this inhibitory effect was observed with the supernatant of Ef7121m (EIm) and with co-incubation with the mutant strain (EIIIm). The Ef7121 mutant strain lacks a plasmid that is present in the wild-type strain (Sparo et al. 2006). Electrophoretic analysis of plasmid DNA demonstrated that Ef7121 contains only one plasmid, which is responsible for the production of antimicrobial peptide (AP, such as bacteriocin), a protein that possesses broad inhibitory activity against Gram-positive and Gram-negative bacteria (Sparo et al. 2006). When the mutant strain was used, the effect on T. canis larval viability was reduced but a larvicidal property remained. The finding that only $28 \%$ and $39 \%$ of the larvae showed diminished viability with the Ef7121 mutant indicated that other substances secreted by the wild strain, along with AP, caused $94-100 \%$ inactivation of the larvae, as demonstrated by the EI, EII and EIII experiments. Electron microscopy revealed that some Ef7121 adhered to the surfaces of the larvae, suggesting an additional antagonist activity of the strain against the larvae via the direct contact between both organisms.

The in vivo experiments showed that oral administration of Ef7121 for three consecutive days produced adverse effects on the penetration of T. canis into the intestinal mucosa, as evidenced by the significantly reduced larval counts in the liver and lung when the challenge took place immediately following the last administration (Group A). The potential probiotic survives in the murine intestinal tract, generates significant protection against $T$. canis infection and does not displace the normal microbial flora. The major penetration sites for T. canis larvae in the small intestine are the crypts of Lieberkuhn (Fan et al. 2004). Pérez et al. (2001) reported that the capacity of some probiotic strains to associate intimately with intestinal epithelial cells might modify the apical cell microenvironment where most pathogens attach. The adherence of the ECECT7121 strain to the small intestine reduced the passage of larvae into mice. This antiparasitic effect might be due to a competitive exclusion of larval adherence and/or to the larvicidal activity demonstrated by Ef7121 when it was cultivated in vitro. Nevertheless, the percentage of inhibitory activity obtained from the in vivo experiments was lower than that obtained in vitro, indicating a loss of the inhibitory effect in the intestinal lumen. AP and other substances secreted by $E f 7121$ were likely destroyed or antagonized in the lumen of the intestine; however, this effect was only partial because the inhibitory effect remained significant. 
TABLE

Toxocara canis larvae after incubation with Ef7121

\begin{tabular}{lcccccc}
\hline Larvae state & $\begin{array}{c}\text { EI } \\
(\%)\end{array}$ & $\begin{array}{c}\text { EIm } \\
(\%)\end{array}$ & $\begin{array}{c}\text { EII } \\
(\%)\end{array}$ & $\begin{array}{c}\text { EIII } \\
(\%)\end{array}$ & $\begin{array}{c}\text { EIIIm } \\
(\%)\end{array}$ & $\begin{array}{c}\text { EIV } \\
(\%)\end{array}$ \\
\hline 3 & 2 & 41 & 0 & 0 & 40 & 84 \\
2 & 4 & 20 & 0 & 0.8 & 31.6 & 8 \\
1 & 94 & 39 & 100 & 99.2 & 28.3 & 8 \\
\hline
\end{tabular}

EI and EIm: T. canis larvae incubated in the supernatant from Enterococcus faecalis CECT7121 (Ef7121) (EI) and Ef7121m (EIm) grown in BHI; EII: T. canis larvae incubated in Ef7121 pre-culture; EIII and EIIIm: T. canis larvae coincubated with Ef7121 (EIII) and Ef7121m (EIIIm); EIV: T. canis larvae incubated in BHI broth without bacterial inoculum (control group); 1: dead larvae; 2 : mobile larvae using part of the body; 3: larvae using all the body.

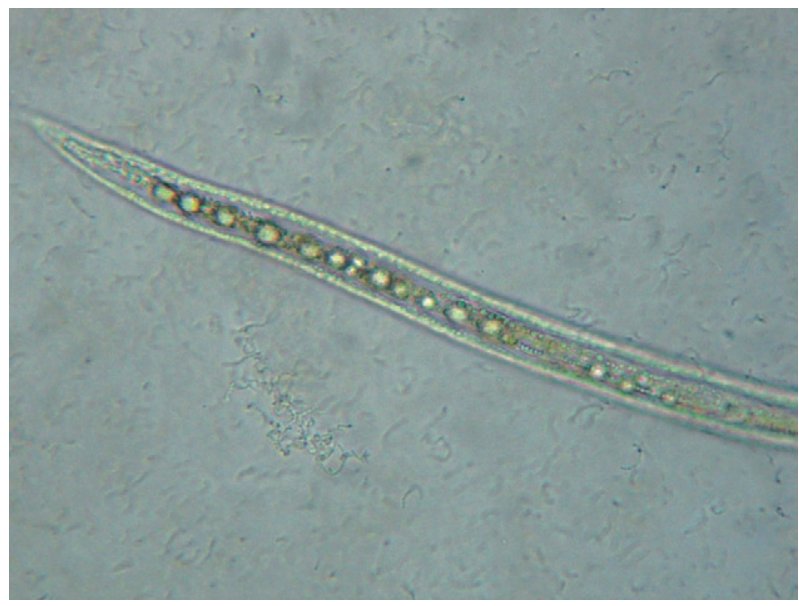

Fig. 1: light micrograph of dead larva incubated with Enterococcus faecalis CECT7121 (EIII) observed at 400X.

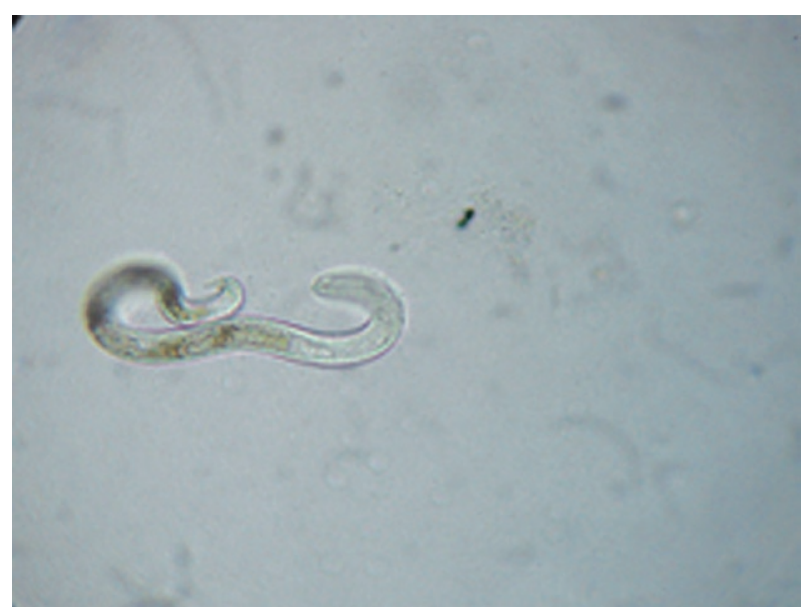

Fig. 2: light micrograph of live larva incubated in brain heart infusion broth (experiment IV).

Another property attributed to probiotics is the modulation of the host immune response. Some of these effects have been attributed to an elevated innate immune response and others to enhancement of the adaptive

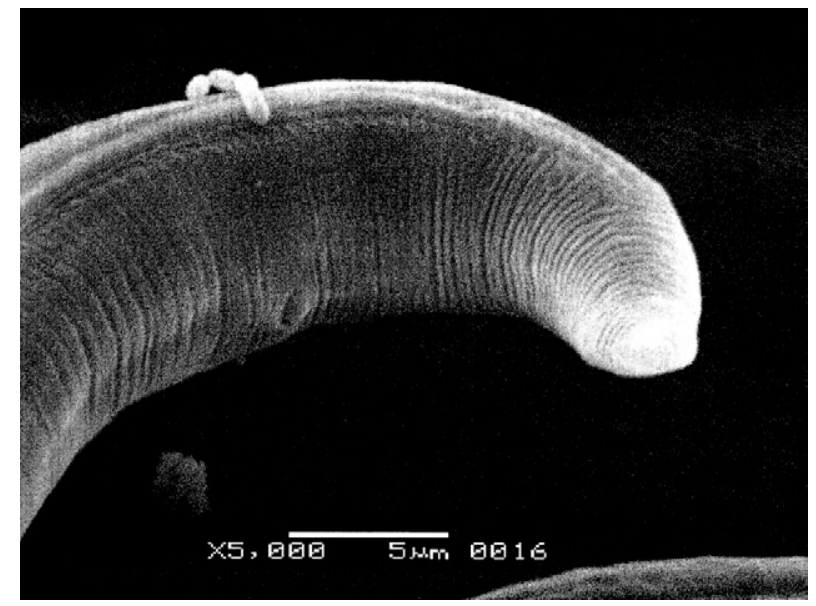

Fig. 3: electron micrograph of Enterococcus faecalis CECT7121 and Toxocara canis larvae.

immune response (Galdeano \& Perdigón 2006). Using in vivo studies, these authors have demonstrated that the main immune mechanism induced by the probiotic strain L. casei CRL 431 is an increased innate immune response leading to the clonal expansion of the IgA Bcell population. In addition, the toll-like receptors (TLR) recognise distinct microbial components and induce innate immune responses. TLR5 is mainly expressed on intestinal CD11 ${ }^{+}$lamina propia cells. These cells detect pathogenic bacteria and secreted proinflammatory cytokines (Uematsu \& Akira 2009). The results obtained in the present study could be associated with the above mentioned effects; however, further studies needed to confirm this hypothesis.

The results also showed that the protection provided by Ef7121 decreased even though the bacterial counts were maintained. The antagonist effect was reduced when the challenge was given 15 days after the last administration of Ef7121, indicating the need for a longterm administration of the strain to maintain the inhibitory effects on larval migration, as previously described for other probiotics (Guitard et al. 2006). We can infer that the persistence of this strain in the intestine is not related to its inhibitory activity, which suggests that sub- 


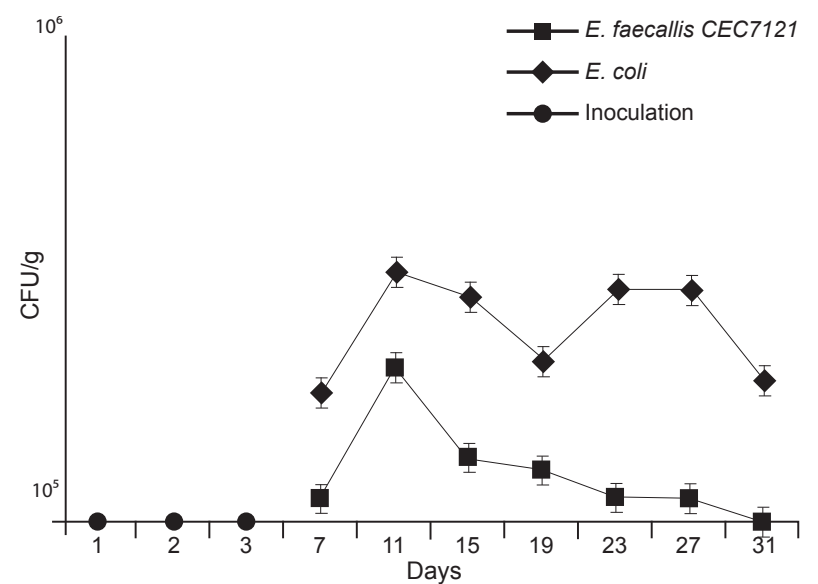

Fig. 4: study of persistence. Counts of Enterococcus faecalis CECT7121 given orally for three consecutive days. Data are represented as colony forming units (CFU)/gram of intestine. Counts of Escherichia coli (normal flora).

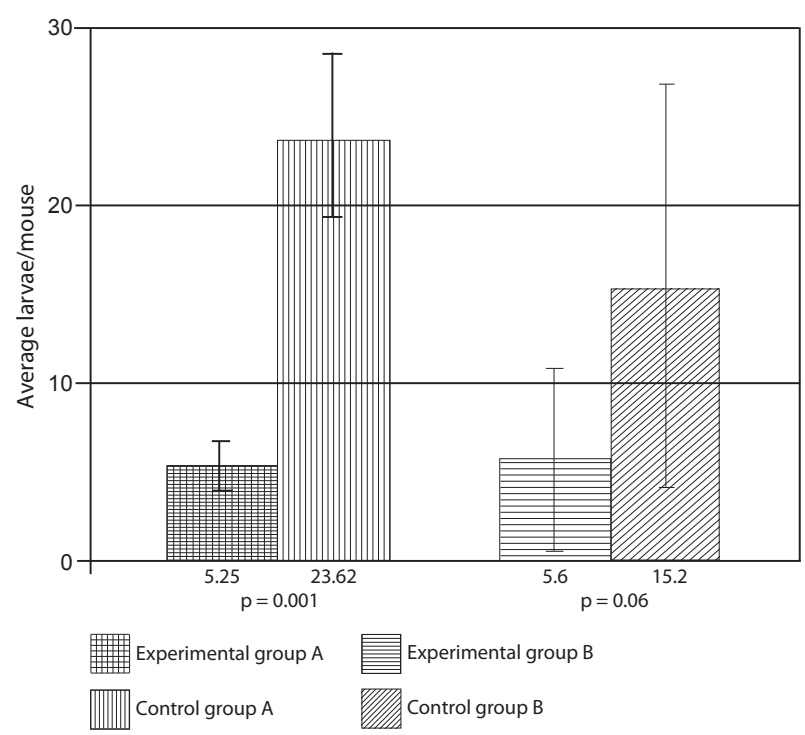

Fig. 5: average quantity of Toxocara canis larvae recovered from mouse liver and lung, after three days (Group A) and after 18 days (Group B) post-treatment with Enterococcus faecalis CECT7121.

sequent generations of $E f 7121$ in the murine intestine will lose their larvicidal activity. This phenomenon may be related to plasmid loss or due to the interference of the indigenous intestinal flora (Boe \& Rasmussen 1996).

Indigenous bacteria, viruses and toxins, which are normally confined within the gastrointestinal tract, may reach systemic organs and tissues, a process termed translocation. Animal models suggest that bacterial adherence by enterovirulent organisms preferentially damage the ileal-caecal mucosa, increasing its permeability and facilitating bacterial translocation (Duffy 2000). Gautreaux et al. (1994) suggest that the levels of caecal population are a major factor in promoting bacte- rial translocation from the gastrointestinal tract. In the evaluated murine model, Ef7121 did not demonstrate bacterial translocation. This lack of translocation might be because this strain does not adhere in the large intestine and because the Ef7121 levels in the small intestine enhance an immune response that restricts excessive growth of the strain, thus preventing its translocation. The bacteria that translocate most efficiently, such as Salmonella typhimurium and L. monocytogenes (Duffy 2000), are classified as facultative intracellular pathogens; Ef7121 is not included in this class (Sparo et al. 2008). In addition, all mice that received the probiotic remained healthy for the duration of the study. There were no signs of diarrhoea, weight loss or loss of appetite. Ef77121 is safe for administration because it lacks pathogenicity and infectivity in the murine model.

In conclusion, previously reported results and those reported herein have demonstrated that Ef7121 possesses in vitro and in vivo larvicidal activity. The antiparasitic effect observed in vitro, and likely in vivo, might be attributable to a secreted AP as well as other substances that modify $T$. canis larval penetration into the intestinal submucosa and/or a competitive action against larval adherence to the intestinal epithelium. Several features of this strain are similar to other probiotics.

However, the mechanism by which Ef7121 exercises larvicidal activity remains unknown. Further research, including fractionation and chemical analysis of the bacterial supernatants, is needed to identify the products involved in the antagonistic effects of Ef7121 on the viability and infectivity of $T$. canis larvae.

\section{ACKNOWLEDGEMENTS}

To Evangelina Bertucci and Verónica Sergnese, for their collaboration.

\section{REFERENCES}

Alak JI, Wolf BW, Mdurvwa EG, Pimentel-Smith GE, Kolavala S, Abdelrahman H, Suppiramaniam V 1999. Supplementation with Lactobacillus reuteri or L. acidophilus reduced intestinal shedding of Cryptosporidium parvum oocysts in immunodeficient C57BL/6 mice. Cell Mol Biol 45: 855-863.

ANMAT - Administración Nacional de Medicamentos, Alimentos y Tecnología Médica 1996. Disposición nº 634. Available from: fcv. unl.edu.ar/bioterio/guias/ANMAT6344.pdf.

Basualdo J, Sparo M, Chiodo P, Ciarmela M, Minvielle M 2007. Oral treatment with a potential probiotic (Enterococcus faecalis CECT7121) appears to reduce the parasite burden of mice infected with Toxocara canis. Ann Trop Med Parasitol 101: 559-562.

Bautista-Garfias CR, Fernández-Román AR, Posadas-Beltrán A, Ixta-Rodriguez O 2002. Increase of resistance against murine experimental Trichinella spiralis infection using Lactobacillus casei. Vet Mex 33: 173-177.

Bautista-Garfias CR, Gómez M, Aguilar BR, Ixta O, Martínez F, Mosqueda J 2005. The treatment of mice with Lactobacillus casei induces protection against Babesia microti infection. Parasitol Res 97: 472-477.

Bautista-Garfias CR, Ixta-Rodríguez O, Martínez-Gómez F, López MG, Aguilar-Figueroa BR 2001. Effect of viable or dead Lactobacillus casei organisms administered orally to mice on resistance against Trichinella spiralis infection. Parasite 8 (Suppl. 2): S226-228.

Benítez T, Rey M, Delgado-Jarana J, Rincón AM, Limón MC 2000. 
Mejoras de cepas de Trichoderma para su empleo como funguicidas. Rev Iberoam Micol 17: 31-36.

Boe L, Rasmussen KV 1996. Suggestions as to quantitative measurements of plasmid loss. Plasmid 36: 153-159.

Chiodo P, Basualdo J 2008. Toxocariosis. Temas de zoonosis IV, Asociación Argentina de Zoonosis, Buenos Aires, p. 349-354.

Chiodo P, Basualdo J, Ciarmela L, Pezzani B, Apezteguía M, Minvie1le M 2006. Related factors to human toxocariasis in a rural community of Argentina. Mem Inst Oswaldo Cruz 101: 397-400.

De la Fé Rodríguez P, Duménigo Ripoll BE, Brito Alberto E, Aguiar Sotelo J. Toxocara canis y síndrome larva migrans visceralis. Red Vet [Revista Electrónica de Veterinaria]. 2006 April [cited 2009 Nov 10]; VII (4): [about 42 p.]. Available from: veterinaria. org/revistas/redvet/n040406.html.

de Vrese M, Schrezenmeir J 2008. Probiotics, prebiotics, and synbiotics. Adv Biochem Eng Biotechnol 111: 1-66.

Dea-Ayuela MA, Rama-Iñiguez S, Bolás-Fernandez F 2008. Enhanced susceptibility to Trichuris muris infection of $\mathrm{B} 10 \mathrm{Br}$ mice treated with the probiotic Lactobacillus casei. Int Immunopharmacol 8: 28-35.

Despommier D 2003. Toxocariasis: clinical aspects, epidemiology, medical ecology and molecular aspects. Clin Microbiol Rev 16: 265-272.

Duffy LC 2000. Interactions mediating bacterial translocation in the immature intestine. J Nutr 130 (Suppl. 2): 432S-436S.

Duggan C, Gannon J, Walker WA 2002. Protective nutrients and functional foods for the gastrointestinal tract. Am J Clin Nutr 75: 789-808.

Fan CK, Hung CC, Lin YH, Li MH, Su KE 2004. Enhanced expression of transforming growth factor-betal in inflammatory cells and secretory granules in Paneth cells in the small intestine of mice infected with Toxocara canis. Parasitol Res 94: 397-404.

Galdeano CM, Perdigón G 2006. The probiotic bacterium Lactobacillus casei induces activation of the gut mucosal immune system through innate immunity. Clin Vaccine Immunol 13: 219-226.

Gautreaux MD, Deitch EA, Berg RD 1994. Bacterial translocation from the gastrointestinal tract to various segments of the mesenteric lymph node complex. Infect Immun 62: 2132-2134.

Guitard J, Menotti J, Desveaux A, Alimardani P, Porcher R, Derouin F, Kapel N 2006. Experimental study of the effects of probiotics on Cryptosporidium parvum infection in neonatal rats. Parasitol Res 99: 522-527.

Heyman M 2000. Effect of lactic acid bacteria on diarrheal diseases. J Am Coll Nutr 19 (Suppl. 2): 137S-146S.

Holland C, Smith H 2006. Introduction. In CV Holland, HV Smith, Toxocara, the enigmatic parasite, CABI Publishing, United Kingdom, p. 1-3.

Humen MA, De Antoni GL, Benyacoub J, Costas ME, Cardozo MI, Kozubsky L, Saudan KY, Boenzli-Bruand A, Blum S, Schiffrin EJ, Pérez PF 2005. Lactobacillus johnsonii La1 antagonizes Giardia intestinalis in vivo. Infect Immun 73: 1265-1269.

Koch S, Hufnagel M, Theilacker C, Huebner J 2004. Enterococcal infections: host response, therapeutic and prophylactic possibilities. Vaccine 22: 822-830.

Magnaval JF, Glickman LT, Dorchies P, Morassin B 2001. Highlights of human toxocariasis. Korean J Parasitol 39: 1-11.
Minvielle MC, Taus MR, Ciarmela ML, Francisconi M, Barlasina M, Pezzani BC, Gasparovic A, Raffo A, Goldaracena C 2003. Aspectos epidemiológicos asociados a toxocarosis en Gualeguaychú, Entre Ríos, Argentina. Parasitol Latinoamer 58: 128-130.

Minvielle MC, Taus MR, Raffo A, Ciarmela ML, Basualdo JA 2000. Seroprevalence of toxocariasis in blood donors of Gualeguaychú, Argentina. Trans R Soc Med Hyg 94: 373-375.

Oshima T 1961. Standardization of techniques for infecting mice with Toxocara canis and observations on the normal migration routes of the larvae. $J$ Parasitol 47: 652-656.

Pavan S, Desreumaux P, Mercenier A 2003. Use of mouse models to evaluate the persistence, safety and immune modulation capacities of lactic acid bacteria. Clin Diagn Lab Immunol 10: 696-701.

Pecinali NR, Gomes RN, Amendoeira FC, Bastos AC, Martins MJ, Pegado CS, Bastos OM, Bozza PT, Castro-Faria-Neto HC 2005. Influence of murine Toxocara canis infection on plasma and bronchoalveolar lavage fluid eosinophil numbers and its correlation with cytokine levels. Vet Parasitol 134: 121-130.

Pereira DI, Basualdo JA, Minvielle MC, Pezzani B, Pagura E, De Marco E 1991. Catastro parasitológico. Helmintiasis en canes. Área: Gran La Plata. Sobre 1000 casos. Vet Arg 7: 165-172.

Pérez PF, Minnaard J, Rouvet M, Knabenhans C, Brassart D, De Antoni GL, Schiffrin EJ 2001. Inhibition of Giardia intestinalis by extracellular factors from Lactobacilli: an in vitro study. Appl Environ Microbiol 67: 5037-5042.

Pollmann M, Nordhoff M, Pospischil A, Tedin K, Wieler LH 2005. Effects of a probiotic strain of Enterococcus faecium on the rate of natural chlamydia infection in swine. Infect Immun 73: 4346-4353.

Rolfe RD 2000. The role of probiotic cultures in the control of gastrointestinal health. J Nutr 130 (Suppl. 2S): 396S-402S.

Sánchez Thevenet P, Jensen O, Mellado I, Torrecillas C, Raso S, Flores ME, Minvielle MC, Basualdo JA 2003. Presence and persistence of intestinal parasites in canine fecal material collected from the environment in the Province of Chubut, Argentine Patagonia. Vet Parasitol 117: 263-269.

Satou T, Horiuchi A, Akao N, Koike K, Fujita K, Nikaido T 2005. Toxocara canis: search for a potential drug amongst beta-carboline alkaloids-in vitro and mouse studies. Exp Parasitol 110: 134-139.

Schrezenmeir J, de Vrese M 2001. Probiotics, prebiotics and synbiotics-approaching a definition. Am J Clin Nutr 73 (Suppl. 2): 361S-364S.

Sparo M, Nuñez GG, Castro M, Calcagno M, García Allende MA, Ceci M, Najle R, Manghi M 2008. Characteristics of an environmental strain, Enterococcus faecalis CECT7121, and its effects as additive on craft dry-fermented sausages. Food Microbiol 25: 607-615.

Sparo MD, Castro MS, Andino PJ, Lavigne MV, Ceriani C, Gutiérrez GL, Fernández MM, De Marzi MC, Malchiodi EL, Manghi MA 2006. Partial characterization of enterocin MR99 from a corn silage isolate of Enterococcus faecalis. J Appl Microbiol 100: 123-134.

Sparo MD, Mallo RA 2001. Evaluation of the bacterial flora in natural corn silage. Rev Argent Microbiol 33: 75-80.

Uematsu S, Akira S 2009. Immune responses of TLR5(+) lamina propia dendritic cells in enterobacterial infection. $J$ Gastroenterol 44: 803-811.

Waghorn TS, Leathwick DM, Chen LY, Gray RA, Skipp RA 2002. Influence of nematophagous fungi, earthworms and dung burial on development of the free-living stages of Ostertagia (Teladorsagia) circumcincta in New Zealand. Vet Parasitol 104: 119-29. 